\title{
Back to Basics: A Critique of the Strengths Perspective in Social Work
}

\author{
Mel Gray
}

\begin{abstract}
This article takes an in-depth look at the strengths perspective, examining its philosophical roots, its core characteristics (according to its key proponents), and its limitations. It suggests that the strengths perspective is underpinned by a mix of Aristotelianism, humanistic individualism, and communitarianism. The article highlights the synergies between the strengths perspective and contemporary neoliberalism and suggests the need to go back to basics to achieve some distance from the harsher aspects of welfare reform policy, which affect most domains of social work practice. It ends with some suggestions as to how the limitations of the strengths perspective might be addressed, in order to devise a more complete theory for social work practice.
\end{abstract}

\section{IMPLICATIONS FOR PRACTICE}

- A broader understanding is needed of the tenets and claims of the strengths perspective and its links with neoliberalism.

- More guarded claims about the strength of social capital, community, and community development should be incorporated.

- Greater empirical support is necessary of the effectiveness of strengths-based interventions.

$\mathbf{T}$ hough the "social work profession has historically identified itself as a profession that focuses on [client] strengths" (Waller \& Yellow Bird, 2002, p. 49) and "there has always been a capacity-building aspect to problem-focused frameworks" (McMillen, Morris, \& Sherraden, 2004, p. 318), the originators of the strengths perspective (Early \& Glenmaye, 2000; Kisthardt, 1994; Rapp, 1998; Saleebey, 1992, 1996; Weick, Rapp, Sullivan, \& Kisthardt, 1989) claim that it represents "a dramatic departure from conventional social work practice" (Saleebey, 2002, p. 1) and "a more apt expression of some of the deepest values of social work" (Weick et al., 1989, p. 350). The approach was popularized by Dennis Saleebey's edited collection of readings in The Strengths Perspective in Social Work Practice (1992; 2nd ed., 1997; 3rd ed., 2002; 4th ed., 2005; 5th ed., 2009). It reflects a trend of the past 15 years whereby "social workers have been encouraged to refashion themselves into strengths-based, solution-focused, capacity building, asset creating, motivation enhancing, [and] empowerment specialists" (McMillen et al., 2004, p. 317). Staudt, Howard, and Drake (2001) referred to it as a poorly defined approach that was not much different from other approaches and lacked evidence of its effectiveness. But for pragmatist Saleebey (2002), its importance and usefulness "lies not in some independent measure of its truth, but in how well it serves us in our work" (p. 20). Notwithstanding its critics, the strengths perspective has achieved a following in contemporary social work. While McMillen et al. (2004) provided an historical account locating the strengths perspective in inter alia client-focused approaches; ego and developmental psychology; and ecological, ecosystems, or person-in-environment approaches (see also Compton \& Gallaway, 1999; Hamilton, 1951; Perlman, 1957; Smalley, 1971; Towle,
1965), no one has yet traced its philosophical roots and its core characteristics stemming from these foundations.

\section{Tracing the Philosophical Roots of the Strengths Perspective}

The strengths perspective in social work has its philosophical roots in Aristotle's teleological theory of human flourishing or eudaimonia. Eudaimonism holds that people should strive to reach their innate potential through the exercise of their capabilities, most importantly, their reason and intellect. It grounds ethics in human nature and links human flourishing to following the virtues. It is only by living a virtuous life that human beings can actualize their true nature. Hence values exist because of the needs and requirements of human beings. It is a humanistic theory that rejects the idea that morality can be explained and maintained by a system of rules and duties (deontology) or in terms of consequences (consequentialism) or maximizing the good (utilitarianism). Rather, it is built upon the belief that all human beings have innate capacities and an essence, or imprint, which drives them toward their natural end point-the conditions of their own flourishing through use of their reason and innate capacities. Aristotle-and the strengths perspective-gives pride of place to notions of freedom, self-determination, and responsibility. Human flourishingeudaimonia-only occurs as a result of individual choice and action:

Eudaimonia consists in a person taking charge of his own life so as to develop and maintain those ends (those virtues) for which he is alone responsible and which in most cases will allow him to attain the goods his life requires.... If a person is to flourish, he must direct himself... [with others in mind]. (Rasmussen \& Den Uyl, 1991, p. 63, emphasis in original)

The strengths perspective combines these central Aristotelian notions with a Kantian deontological sense of obligation and duty to actualize potential through well-reasoned behavior (Gray, 2010; Herman, 1993). The human being's capacity for self-actualization formed the basis of Carl Rogers's existential-humanistic, client-centered approach to psychotherapy (Boeree, 2006). Rogers (1951) operated from a strengths perspective-although not recognized as such at the time- 
seeing people as inherently good or healthy or, at the very least, not bad or ill. For Rogers, mental health is the normal trajectory of life, and mental illness, criminality, and other human problems are distortions of the natural human tendency toward progressive development. Consistent with utilitarianism, Rogers's theory is built on a single life force or actualizing tendency, a built-in motivation present in every life form to develop to its maximum potential. It is not merely a matter of the human survival instinct but a built-in striving to make the very best of existence. All organisms, as a result of evolutionary processes, have an organismic valuing system that enables them to determine and access what is good for them. Among these desirables are positive regard, Rogers's collective term for love, admiration, recognition, affection, attention, nurturance, and so on, and positive self-regard or self-esteem, self-worth, and a positive self-image, without which humans feel helpless and worthless. The pivotal point of Rogers's nondirective psychotherapeutic approach is his belief in the individual's capacity to deal constructively with problems within the context of a safe, nurturing relationship where the counselor demonstrates acceptance and positive regard for clients and their ability to take charge of their life. Rather than focus on behavioral change, as was the way of the dominant behaviorist paradigm, Rogers emphasized the importance of the clienttherapist relationship in his person-centered approach, built on the core conditions of warmth, empathy, and genuineness, which fostered trust and enabled clients to realize and exercise their full potential.

The humanistic approach was widely adopted in social work (Goldstein, 1988). However, this naturalistic theory of people's innate capacities and drive toward human flourishing separated from its moral home (Goldstein, 1987) could all too easily seem remarkably compatible with contemporary Third Way, that is, neoliberal individualism and the shifting of responsibility onto individuals and families within the restructured welfare state. This humanistic individualism, the second philosophical pillar of the strengths perspective, is bolstered by communitarianism, its third pillar. Here the "human capabilities approach" proposed by economist Amartya Sen (1985) and later developed with Martha Nussbaum (Nussbaum, 2000; Nussbaum \& Sen, 1993) and Putnam's (2000) theory of social capital have become most influential. These theories draw on Aristotle's political theory about the conditions needed in the polis, or city-state, for human flourishing (Kristjánsson, 2007). Common to all is recognition of human capabilities and the conditions for their realization. Using these principles, Kretzmann and McKnight (1993) developed their assets-based community development (ABCD) approach to community capacity building (see also McKnight \& Kretzmann, 1996) embraced by the strengths perspective.

These communitarian approaches, inspired by a recent Aristotelian revival set in motion by Alasdair MacIntyre (1981), Amartya Sen, Martha Nussbaum, and others, have become a cornerstone of neoliberal Third Way social policy and the devolution of responsibility onto individuals, families, and communities. The neoliberal embrace of the core philosophical foundations of the strengths perspective requires that the perspective goes back to basics to rethink ways of distancing itself from the harsher aspects of contemporary welfare policy. As McRobbie (2009) noted, in relation to feminism, in the hands of neoliberal politicians, it is hard to recognize the value-based practice that empowerment entails.

\section{An In-Depth Look at the Strengths Perspective}

Saleebey (2002) believed that the strengths perspective, though "not yet a theory...is a way of thinking... a distinctive lens for examining the world of practice" (p. 20), wherein everything social workers do is premised on discovering, embellishing, exploiting, and exploring client strengths. The problem, as he sees it, with conventional helping is that it sees the person as the problem; expresses a language of professional cynicism and doubt; distances the worker from the client in unequal, controlling, and manipulating relationships; strips problems of their context; and supposes a disease with a cause and a solution. Perlman's (1957) person with a problem becomes the person is the problem, as clients are pathologized and victimized through categorization and labeling, especially through the American Psychiatric Association (APA) classification of mental disorders in the Diagnostic and Statistical Manual of Mental Disorders (4th ed., text rev., DSM-IV$T R$; see Saleebey, 2002, p. 2). Generally, when people have problems, diagnoses and assessments are made that focus on what's wrong with them. Though the strengths perspective might appear straightforward and make good sense, Saleebey (2002) believed its complexity is grossly underestimated, given the obstacles to implementing a non-problem-solving framework in social work. In contrast, strengths-based approaches invite practitioners-and clients-to focus on what's right with them-on the positives in the situation-the things they can do or what Nietzsche referred to as their "will to power." Thus advocates of the strengths perspective see it as a radical alternative to the mainly deficits-focused, disease-oriented intervention models currently in vogue. For them it is a form of resistance in that it questions

the dominant deficiency-based mental health paradigm that pigeonholes people in terms of pathology and assigns them disempowering labels; anti-oppressive practice models that construe clients as oppressed and immediately engender feelings of powerlessness; and rigid mindsets such as positivism, ardent feminism and structuralism that lead practitioners to approach the helping situation with preconceived ideas that influence the way they listen to, hear and interpret the client's story and thus the way in which they design their interventions. (Gray \& Collett van Rooyen, 2002, p. 193)

In contrast, strengths-based approaches, it is claimed, include empowering helping models, such as narrative therapy (Freedman \& Combs, 1996; White \& Epston, 1990), brief solution-focused therapy (de Shazer, 1985, 1988), ABCD (McKnight \& Kretzmann, 1996), participatory research (Gray \& Collett van Rooyen, 2002), and inductive social policy development (Chapin, 2006; Jones \& Bricker-Jenkins, 2002). It embraces several social and psychological theories building on these ideas, including Erickson's life-stage theory and the developmental perspective, which understands that individuals pass through several stages on the road to self-actualization.

With its theoretical origins in several diverse but related fields, the strengths perspective has an eclecticism about it. It is compatible with integrative frameworks, like Germain's (1973) ecological model, Pincus and Minahan's (1973) systems model, and Germain and Gitterman's (1981) life model, as practitioners are exhorted to think ecologically and see individuals as part of families, groups, and communities, which are "a function, at least in part, of the resources available to people" (Sullivan \& Rapp, 2002, p. 248) in the environment in which they live. These prior models follow a rational problem-solving approach of assessment and intervention. However, the strengths perspective favors an inductive approach, whereby insights emerge through the relationship with the clients and the stories they 
tell. It fits harmoniously with diverse postmodern-narrative, spiritual, and multicultural-perspectives emerging in social work, which favor an interpreted view of reality. Goldstein (2002) saw these generative frameworks as yet another addition to the rich legacy of humanistic thinking that permeates social work knowledge for practice. Goldstein correctly observed that social work is grounded strongly in humanistic individualism, which forms the basis for many psychological theories of human development and varieties of client or person-centered therapy as well as contemporary social theories adopted by strengths practitioners. What then might we deduce about the strengths perspective from its main advocates?

\section{Characteristics of the Strengths Perspective}

Naturalistic, normative approach. The strengths perspective orients social workers to their obligations to themselves and their clients (see Saleebey, 2002, p. xvii). It takes a Kantian-and liberal-view of the person as rational and self-determining, that is, as capable of making one's own choices and decisions. It assumes "client competence" (Cowger \& Snively, 2002, p. 111) and, on this basis, holds each person responsible for his or her own behavior and recovery. Thus, said Saleebey (2002), "everyone has the potential for self-righting, [for] self-correction of [the] life course" (p. 234). It also implies that clients can only do this with the intervention of the strengths-based social worker: "people can grow only when the social worker actively affirms and supports their ability to do so" (Weick et al., 1989, p. 354). It requires practitioners to give preeminence to the client's understanding of the facts. The social worker believes the client, explores and discovers what the client wants, uses the client's words, makes assessment a joint or collaborative activity, reaches mutual agreement, avoids blame and blaming and cause-effect thinking, and assesses rather than diagnoses (see Cowger \& Snively, 2002, pp. 113-115). Strengths must be located and nurtured. For Fast and Chapin (2002), its value base is grounded in human beings' natural potential to grow, heal, and learn; on their ability to identify wants; on the strengths of the person and environment; and self-determination, individuality, and uniqueness (see p. 147).

Humanistic foundations. Essentially, the strengths perspective is "a way of thinking....and seeing" (Saleebey, 2002, pp. xvii, 1). One can discern its Aristotelian grounding in the language it uses: It is rooted in a belief in the innate human potential to function as "individuallyfulfilled, socially contributive person[s]" (Smalley, 1967, p. 1). It is a humanistic approach that sees strengths as "personal qualities, traits, [talents] and virtues" (Saleebey, 2002, p. 85, emphasis in original). Also,

\footnotetext{
a strengths perspective rests on an appreciation of the positive attributes and capabilities that people express and on the ways in which individuals and social resources can be developed and sustained...[on] a belief in human potential...[and] capacity for continued growth and heightened well-being. (Weick et al., 1989, p. 352)
}

It is founded on a belief in every individual's "innate resilience" (Benard, 2002, p. 215), "inherent capacity," and inner wisdom to determine what is in their best interests (Weick \& Pope, 1988, cited by Weick et al., 1989, p. 353). It looks toward possibility, hope, and transformation (Saleebey, 2002) as "the question is not what kind of life one has had, but what kind of life one wants" (Weick et al., 1989, p. 353).

Centrality of relationships. Relationships are a central focus of the strengths perspective because their importance in social work has been lost and needs revitalizing. Goldstein (2002) extolled the value of the strengths-based relationship between client and worker as the moral bulwark of social work. First and foremost, strengths are features of relationships based on mutuality and connection with each other, as well as respect for and affirmation of human dignity. The influence of narrative therapy is evident in Saleebey's (2002) claim that strengths-based practitioners acknowledge their clients' pain, stimulate discourse and narratives about their clients' strengths and resilience, act in context, normalize the problem, and capitalize on strengths and opportunities (see pp. 90-91). The two-way process of mutuality and empathy gives weight to the therapist's ability to foster trusting relationships and offers "a humanistic means of joining with clients" (Goldstein, 2002, p. 33). Though the client's word is believed, it is the therapist's obligation to steer clients in the direction of their strengths-while not minimizing or ignoring their problems-by inviting, inspiring, encouraging, questioning, and empowering them to recognize and realize their potential in the best Aristotelian tradition.

\section{Postmodern and Social Constructionist Orientation}

For Saleebey (2002), "any approach to practice, in the end, is based on interpretation of the experiences of practitioners and clients and is composed of assumptions, rhetoric, ethics, and a set of methods" (p. 20). The strengths perspective eschews professional expertise and scientific knowledge for common sense, tacit knowing, hunches, and guesses (see Saleebey, 2002, p. 6). Its generative approach rejects the need for objective knowledge, the idea of objectivity, and an objective reality_-"the Real" (Witkin, 2002, p. xiv)_for a social constructionist interpretivist view of "the real." Ergo, reality, including strengths and resilience, is socially constructed, and the most important interpretations create "useful realities" that derive from client interpretations and meanings, stories and narratives. Essentially, the strengths perspective takes an instrumental, utilitarian view of knowledge, placing maximum import "on how well it serves us [as professionals] in our work with people, how it fortifies our [professional] values, and how it generates opportunities for clients in a particular environment to change in the direction of their hopes and aspirations" (Saleebey, 2002, p. 20). Above all, it values interpretations of reality with "transformational potential" (Witkin, 2002, p. xiv). In so doing, it is said to be quietly fostering "a small revolution" wherein "resilience...is rebounding, and collaborative practice is growing" (Witkin, 2002, p. xv).

With its narrative approach, the strengths perspective focuses on those interpretations of reality that help people change or surmount difficulties, and it expresses "cynicism" about the "language of pessimism and doubt" (Saleebey, 2002, p. 4), which pervades clinical mental health practice. Social workers must change the way they think about clients, and an important part of this change lies in changing the language they use in their conversations with clients and with fellow workers, agency managers, policymakers, and so on. For Goldstein (2002), they must see the client's story-or the narratives people tell-as the "moral center of gravity...the overtones of goodness or badness, of right or wrong, or of evil or virtue that storytellers seem to attribute to their thoughts and actions" (p. 25, emphasis in the original).

\section{Social Justice or Empowerment Orientation}

According to Saleebey (2002), focusing and building on people's strengths is an ethical imperative in "a democratic, just, and pluralis- 
tic society" (p. 264). The strengths perspective assumes a democratic view of the subject: Its "empowerment agenda requires a deep conviction about the necessity of democracy" (Saleebey, 2002, p. 9). It recognizes the distance between client and social worker, the power inequality in the client-worker relationship, and the worker's control and manipulation of the client as the locus for change. It assumes that equality in the client-worker relationship is not only desirable but also possible. It undermines the professional stance, the need for education-engendered expertise and skill, and so on. It positions the social worker as an ally in "a collaborative process" (Saleebey, 2002, p. 1), who invites people to identify and (re)connect with their personal and social resources; inspires them to bear hardships, overcome obstacles, and resist oppression; and encourages action in accordance with the client's goals and on their terms. Thus, it extols user participation and client collaboration as the means by which the client's autonomy is exercised and the client-worker relationship is equalized. The "helping relationship is one of collaboration, mutuality, and partnership-power with one another, not power over another" (Kisthardt, 2002, p. 166).

The strengths perspective sees social justice as its ultimate goal, which calls for a repoliticization of social work. It sees ending poverty as a legitimate end of social work through inter alia community organizing, transformative education, collective action, participatory research, healing through struggle, changing hearts and minds, and supporting self-liberation. It views both research and practice as transformative, political processes (see Jones \& Bricker-Jenkins, 2002). It holds that social workers have "an ethical obligation to develop effective ways to work with people who are economically oppressed" (Jones \& Bricker-Jenkins, 2002, p. 191, emphasis in original). With the social worker as facilitator, it is the client-which can be the community-who does the changing to reconnect with personal and social resources, to bear hardship, to resist oppression, and so on. These personal and social resources are to be found in individuals and then aggregate to "cumulative resources [in] groups in the community" (Saleebey, 2002, p. 237).

Optimistic view of community and social capital. The strengths perspective takes an optimistic view of community and social capital, seeing voluntary associations, self-help groups, and local relationships as community assets and forces for good. Like the individual, the community has the will and resources to help itself and knows what is best for itself (Delgado, 2000, cited by Saleebey, 2002, p. 233). Through community development, professionals create "opportunities for people to be contributing members of their own community" (Saleebey, p. 235, emphasis in original). Hence "a true community...is inviting and encourages participation” (Saleebey, p. 237).

\section{Strong Faith in Liberal Democracy}

The strengths perspective, with its transformational "empowerment agenda requires a deep conviction about the necessity of democracy" (Saleebey, 2002, p. 9): "People need to be citizens, responsible and valued members of a community... [they need to] band together to make their voices heard" (p. 10). It takes an active view of citizenship (see Reynolds, 1951, cited by Saleebey, 2002, p. 18), but "active citizenship" in today's neoliberal environment has become a hinge for punitive welfare reforms to counteract passive dependency on welfare. Thus, as is suggested later, it is important to be aware of the neoliberal co-optation of strengths-based concepts. In neoliberal terms "active citizenship" means "not dependent on welfare" or economically active and has little to do with democratic participation.

\section{Some Problems With the Strengths Perspective}

\section{Strong Links With Liberalism}

While the strengths perspective uses the language of social justice and empowerment, the solutions it suggests are essentially grounded in (neo)liberal notions of individual responsibility, which have their roots in Kantian ethics and utilitarian means-end justification. Like liberalism, it upholds autonomy as an overriding moral ideal, a belief in people's ability to choose with informed consent as the "standard liberal procedure by which agents manifest their autonomy" (Kristjánsson, 2007, p. 45). Liberalism promotes a small core of values, inflating autonomous choice and "the benefits of high self-esteem [which]...fosters the current self-help and therapy culture" (p. 178) of which social work, and especially the strengths perspective, is a part. Kristjánsson (2007) claims that there is little evidence to suggest that high self-esteem on its own produces better, more stable human beings, or that it prevents social problems. It promotes self-understanding, self-control, and self-interest while contemporary multiculturalism suggests the need for a much larger common core of nonindividualistic values "by virtue of the fact that human beings are a single species, sharing the same basic virtues and vices and action and emotion" (Kristjánsson, 2007, p. 179). While the strengths perspective claims to eschew individualism, its view of the rational determining autonomous self is essentially individualistic. It carries this to extremes in its unquestioning acceptance of the client's view of the world.

\section{Uncritical Adoption of Community Development Theory}

In its social justice or empowerment orientation, the strengths perspective draws uncritically on the theory of community development. Though it claims to take structural considerations into account, these are not the main locus of intervention, nor are broader power relations. Its main focus, as outlined earlier, is on equalizing power between social workers and clients, even though this is somewhat unrealistic in the harsh managerial environments in which most social workers work. It fails to take account of evidence of the relationship between structural inequalities, such as race and class, or of mental illness, poverty, and so on. Instead, its political agenda of participation and self-responsibility comes dangerously close to the political project of the conservative New Right, which critics see as devolving social responsibility from neoliberal governments onto local people-poor individuals and families and, more often than not, women-who bear the brunt of the burden of participation (Gray \& Mubangizi, 2009). Grounded more in rhetoric than in reality, the neoliberal discourse of participation is designed to inculcate "morals and values that facilitate social cohesion" (Etzioni, 1995, in Hodgson, 2004, p. 141) through individuals, families, and communities taking responsibility and finding solutions for their own problems. In this way, it blurs the structural causes of social problems (Bryson \& Mowbray, 1981; Hodgson, 2004; Mowbray, 2004).

The strengths perspective needs to guard against an uncritical adoption of community development theory, which takes an overly optimistic view of communities as forces for good. Communities "can just as easily lead to the social exclusion...of marginal and disadvantaged groups" (Mendes, 2006, p. 3) and to the perpetuation of crime and deviance: "Cohesive community groups can and do perpetrate harsh and unjust behaviour on groups that differ from them" (Gray \& Mubangizi, 2009, p. 2). As Cox (2007) noted, "certain forms of solidarity can be very toxic" (p. 510).

There is also an irony in professionals seeking to adopt an anti- 
professionalist stance through collaborative, empowering relationships. The empowerment literature in social work itself stems from two divergent movements: the liberation and self-help movements steeped in neo-Marxist and antiprofessionalist stances, respectively. Both express cynicism about social workers and professions in general that hijack the language of conscientization and normalization to suit their professional ends (Cruikshank, 1999; Jordan, 2004; Karim, 2008; Levy Simon, 1990; Rozario, 1997, 2001, 2002; Ward \& Mullender, 1991). Silent voices-or an inability to speak for themselves-are perceived as an entrée for service organizations and professionals with middle-class values to intervene and to become the voice of the oppressed and the marginalized, as well as their indispensable route to empowerment (Cruikshank, 1999).

\section{Uncritical Links With Social Capital}

The theory of social capital fits well with neoliberal individualism, consumerism, and market choice. With its focus on communities and social networks, it forces attention away from government responsibility onto "local circuits of cooperation and systems of connectedness... [such as] small-scale, local, practical projects" (Jordan, 2008, p. 444). Localized problem solving is seen as preferable to "public agencies, in which self-serving professional groups, officials and politicians are often the chief beneficiaries" (Jordan, p. 445). It shifts the focus from government provision to civil society suggesting that social work should "be more educative and activating, helping poor people learn to aspire to be enterprising, autonomous and innovatory, as individuals and communities.... However, much of the rhetoric of empowerment and inclusion...is vague and aspirational" (Jordan, p. 446; see also Jordan, 2004).

\section{Links to the Subjective Well-Being Movement}

In the hands of neoliberals, empowerment inherent in self-responsibility and active citizenship involves self-governance. This neoliberal project has spawned the subjective well-being movement, which is fueled by notions of developmental resilience, self-esteem engendering healing, wholeness, wellness, happiness, and spirituality (Gray, 2008), which has been warmly embraced by positive psychology. It expresses a relentless optimism about people's capacity to overcome adversity. Rather than acknowledge structural inequalities and research on social indicators of poverty and mental illness, especially their class base, it advances solutions variously situated in individual lifestyle changes, interpersonal relationships, and social networks rather than in structural change. Ultimately, neoliberalism sees health, happiness, and well-being as the individual responsibilities of "democratic subjects" (Cruikshank, 1999), when there is ample evidence that social factors shape every aspect of the human malaise, not least greed and unbridled capitalism.

Jordan (2008) questioned the social well-being perspective and asked whether an alternative analysis of social value more consistent with social work's humanistic concerns can be found. He asked whether the kind of social relations fostered by the promotion of individual capabilities in a market environment are, indeed, conducive to human well-being, in the face of incontrovertible evidence that increased material wealth does not necessarily lead to greater happiness (Inglehart, 1997). As Jordan noted, social work has always claimed to be primarily concerned with human well-being, but it has seldom questioned its links with economic welfare.

Possibly, this is because social work is caught between two value systems, which Inglehart (1997) referred to as modern and postmodern.
Where poverty and economic survival is a major issue, modernization and materialist values are the dominant focus, but in affluent or developed societies, postmaterialist values associated with postmodernization assume prominence. Human well-being associated with economic survival is very different from that associated with postmaterialist life choices where quality of life is chosen over increased economic prosperity. This distinction is important for those who link the strengths perspective to the individual well-being and empowerment movement with its basis in economic individualism. It is a poor replacement for public-sector social work and social services, and it is remarkably consistent with Third Way policy that promotes individual independence and choice. While the well-being perspective provides social workers, whether in affluent or developing countries, with arguments for reasserting the value of relationships and communities for individual and social well-being, it must be balanced with a structural understanding of social reality and the barriers to social development for those whose daily concern is economic survival.

By situating the strengths perspective within a postmaterialist value system, its discourse on spirituality and health realization might be better understood and divorced from neoliberal contamination. Statements on spirituality as involving "honoring and getting in touch with the health and wisdom within" (Saleebey, 2002, pp. 238-239) and claims that "health realization" (Mills, 1995, cited by Saleebey, 2002, p. 239) "builds up from within rather than being imposed from without” (Benard, 1994, cited by Saleebey, 2002, p. 240) come dangerously close to neoliberal individualism, as does the notion that "individual well-being and resilience are part of all community activities; that there is real work, real responsibility, real opportunity... and genuinely positive expectations of success and accomplishment" (Saleebey, 2002, p. 237, emphasis added). Many people, especially the clients that social workers deal with, facing daily economic survival need material aid and cannot work their way out of poverty merely through their own efforts. Therefore, it helps to understand the subjective well-being movement as characteristic of postmaterialist societies where people have the material goods they need and where quality of life means something very different to what it means for poor people faced with economic survival needs (Inglehart, 1997). What sense would Kisthardt's (2002) Personal Wellness Plan make for a street child in Zimbabwe today? (See Kisthardt, p. 182; see also Saleebey, 2002, p. 280.)

\section{Personal, Gendered View of Care}

Care is another example where the strengths perspective sounds ominously neoliberal, using, as it does, political social justice language to advocate for a personal process. It claims that care is essential to individual well-being and is based on three rights: the right of families to care for their members, the right to quality care from paid caregivers, and the right to get the care needed. Yet, almost in the same breath, it sees care as an individual responsibility: "Caring for each other is the most basic form of civic participation...the essential democratic act" (Stone, 2000, cited by Saleebey, 2002, p. 17). For Weick (2000), care is gendered. It is the male-dominated social work profession's "hidden voice" - the hidden voice of its predominantly female social workers. If social work is so political, and if it is a predominantly female profession, why has the women's voice remained hidden?

\section{Conclusion}

The strengths perspective assumes a political activism that does not exist in social work (Gray, Collett van Rooyen, Rennie, \& Gaha 2002; 
Reisch \& Andrews, 2002). While stemming from sound philosophical foundations, it is in danger of running too close to contemporary neoliberal notions of self-help and self-responsibility and glossing over the structural inequalities that hamper personal and social development. The theory of social capital and community development, and the strengths and empowerment approaches they entail, are a weak antidote to the calculative individualism of contemporary neoliberalism. Furthermore, there is a clear lack of empirical support for the claimed success of these strengths-based approaches. To address these limitations, the strengths perspective could benefit from a broader understanding of its tenets and claims within contemporary social work practice contexts and seek to distance itself from the harsher, impersonalizing processes of neoliberal welfare reform. It needs to be more guarded about overly optimistic claims about the strength of social capital, community, and community development. Greater empirical support for the effectiveness of strengths-based interventions is needed beyond descriptive case studies of its successes. While appreciative of the value of the strengths perspective, it's not wise to be overly ambitious in claims about its potential. While its strength lies in its humanizing potential, more than a focus on individual and community capacity is needed to deliver the transformatory agenda it promises.

\section{References}

American Psychiatric Association. (2000). Diagnostic and statistical manual of mental disorders (4th ed., text rev.). Washington, DC: Author.

Benard, B. (2002). Turnaround people and places: Moving from risks to resilience. In D. Saleebey (Ed.), The strengths perspective in social work practice (3rd ed.; pp. 213-227). New York: Longman.

Boeree, C. G. (2006). Carl Rogers: Biography. Retrieved from http://webspace.ship. edu/cgboer/rogers.html

Bryson, L., \& Mowbray, M. (1981). Community: The spray-on solution. Australian Journal of Social Issues, 16(4), 255-267.

Chapin, R. (2006). Social policy for effective practice: A strengths approach. Boston: McGraw-Hill.

Compton, B., \& Gallaway, G. (1999). Social work processes (6th ed.). Homewood, IL: Dorsey Press.

Cowger, C., \& Snively, C. A. (2002). Assessing client strengths: Individual, family, and community empowerment. In D. Saleebey (Ed.), The strengths perspective in social work practice (3rd ed.; pp. 106-123). New York: Longman.

Cox, E. (2007). The functional value of social capital. Australian Journal of Social Issues, 42(4), 503-512.

Cruikshank, B. (1999). The will to empower: Democratic citizens and other subjects. Ithaca, NY: Cornell University Press.

de Shazer, S. (1985). Keys to solution in brief therapy. New York: W.W. Norton.

de Shazer, S. (1988). Clues: Investigating solutions in brief therapy. New York: W.W. Norton.

Early, T. J., \& Glenmaye, L. F. (2000). Valuing families: Social work practice with families from a strengths perspective. Social Work, 45(2), 118-130.

Fast, B., \& Chapin, R. (2002). The strengths model with older adults: Critical practice components. In D. Saleebey (Ed.), The strengths perspective in social work practice (3rd ed.; pp. 143-162). New York: Longman.

Freedman, J., \& Combs, G. (1996). Narrative therapy: The social construction of preferred realities. New York: W.W. Norton.

Germain, C. B. (1973). An ecological perspective in casework practice. Social Casework, 54, 323-330.

Germain, C., \& Gitterman, A. (1981). The life model of social work practice: Advances in theory and practice. New York: Columbia University Press.

Goldstein, H. (1987). The neglected moral link in social work practice. Social Work, 32(3), 181-187.

Goldstein, H. (1988). Humanistic alternatives to the limits of scientific knowledge. Social Thought, 19(1), 181-187.

Goldstein, H. (2002). The literary and moral foundations of the strengths perspective. In D. Saleebey (Ed.), The strengths perspective in social work practice (3rd ed.; pp. 23-47). New York: Longman.

Gray, M. (2008). Viewing spirituality in social work through the lens of contemporary social theory. British Journal of Social Work, 38(1), 175-196.

Gray, M. (2010). Moral sources and emergent ethical theories in social work. British Journal of Social Work.
Gray, M., \& Collett van Rooyen, A. J. (2002). The strengths perspective in social work: Lessons from practice. Maatskaplike Werk [Social Work], 38(3), 225-233.

Gray, M., Collett van Rooyen, A. J., Rennie, G., \& Gaha, J. (2002). The political participation of social workers: A comparative study. International Journal of Social Welfare, 11(2), 99-110.

Gray, M., \& Mubangizi, B. C. (2009). Caught in the vortex: Can local government community development workers in South Africa succeed? Community Development Journal. Retrieved from http://cdj.oxfordjournals.org. doi: $10.1093 / \mathrm{cdj} / \mathrm{bsp} 007$

Hamilton, G. (1951). Theory and practice of social casework (2nd ed.). New York: Columbia University Press.

Herman, B. (1993). The practice of moral judgment. Cambridge, MA: Harvard University Press.

Hodgson, L. (2004). Manufactured civil society: Counting the cost. Critical Social Policy, 24(2), 139-164.

Inglehart, R. (1997). Modernization and postmodernization: Cultural, economic, and political change in 43 societies. Princeton, NJ: Princeton University Press.

Jones, J. C., \& Bricker-Jenkins, M. (2002). Creating strength-based alliances to end poverty. In D. Saleebey (Ed.), The strengths perspective in social work practice (3rd ed.; pp. 186-212). New York: Longman.

Jordan, B. (2004). Emancipatory social work? Opportunity or oxymoron. British Journal of Social Work, 34, 5-19.

Jordan, B. (2008). Social work and world poverty. International Social Work, 51(4), $440-452$.

Karim, L. (2008). Demystifying micro-credit: The Grameen Bank, NGOs, and neoliberalism in Bangladesh. Cultural Dynamics, 20(1), 5-29.

Kisthardt, W. E. (1994). An empowerment agenda for case management research: Evaluating the strengths model from the consumer's perspective. In M. Harris \& H. Bergman (Eds.), Case management for mentally ill patients: Theory and practice. (pp. 112-125). Langhorne, PA: Harwood.

Kisthardt, W. E. (2002). The strengths perspective in interpersonal helping: Purposes, principles, and functions. In D. Saleebey (Ed.), The strengths perspective in social work practice (3rd ed.; pp. 163-185). New York: Longman.

Kretzmann, J. P., \& McKnight, J. L. (1993). Building communities from the inside out: Toward finding and mobilizing a community's assets. Evanston, IL: Northwestern University, Center for Urban Affairs and Policy Research.

Kristjánsson, K. (2007). Aristotle, emotions, and education. Aldershot, UK: Ashgate.

Levy Simon, B. (1990). Rethinking empowerment. Journal of Progressive Human Services, 1(1), 27-39.

MacIntyre, A. (1981). After virtue. London: Duckworth.

McKnight, J., \& Kretzmann, J. P. (1996). Mapping community capacity. Evanston, IL: Institute for Policy Research.

McMillen, J. C., Morris, L., \& Sherraden, M. (2004). Ending social work's grudge match: Problems versus strengths. Families in Society: The Journal of Contemporary Social Services, 85(3), 317-325.

McRobbie, A. (2009). The aftermath of feminism: Gender, culture and social change. London: SAGE.

Mendes, P. (2006). Classic texts. Community Development Journal. Advance Access published May 16, 2006, 1-3. doi: 10.1093/cdj/bsl1009

Mowbray, M. (2004). Beyond community capacity building: The effect of government on social capital. Observatory PASCAL: Place Management, Social Capital and Learning Regions. Retrieved from http://www.obs-pascal.com/

Nussbaum, M. C. (2000). Women and human development: The capabilities approach. Cambridge, UK: Cambridge University Press.

Nussbaum, M. C., \& Sen, A. (Eds.). (1993). The quality of life. Oxford, UK: Clarendon Press.

Perlman, H. H. (1957). Social casework: A problem-solving process. Chicago: University of Chicago Press.

Pincus, A., \& Minahan, A. (1973). Social work practice: Model and method. Itasca, IL: F.E. Peacock.

Putnam, R. (2000). Bowling alone: The collapse and revival of American community. New York: Simon \& Schuster.

Rapp, C. (1998). The strengths model: Case management with people suffering from severe and persistent mental illness. New York: Oxford University Press.

Rasmussen, D. B., \& Den Uyl, D. J. (1991). Liberty and nature: An Aristotelian defense of liberal order. La Salle, Illinois: Open Court Publishing.

Reisch, M., \& Andrews, J. (2002). The road not taken. New York: Brunner-Routledge.

Rogers, C. (1951). Client-centered therapy. Boston: Houghton Mifflin.

Rozario, S. (1997). Development and rural women in South Asia: The limits of empowerment and conscientisation. Bulletin of Concerned Asian Scholars, 29(4), 45-53.

Rozario, S. (2001). Women and poverty: Is Grameen Bank the answer? Journal of Interdisciplinary Gender Studies, 6(2), 60-82. 
Rozario, S. (2002). Grameen Bank-style microcredit: Impact on dowry and women's solidarity. Development Bulletin, 57, 67-70.

Saleebey, D. (Ed.). (1992). The strengths perspective in social work practice. New York: Longman.

Saleebey, D. (1996). The strengths perspective in social work practice: Extensions and cautions. Social Work, 41(3), 296-305.

Saleebey, D. (Ed.). (1997). The strengths perspective in social work practice (2nd ed.). New York: Longman.

Saleebey, D. (Ed.). (2002). The strengths perspective in social work practice (3rd ed.) New York: Longman.

Saleebey, D. (Ed.). (2005). The strengths perspective in social work practice (4th ed.) New York: Longman.

Sen, A. (1985). Commodities and capabilities. Oxford, UK: Oxford University Press Smalley, R. E. (1967). Theory for social work practice. New York: Columbia University Press.

Smalley, R. E. (1971). Social casework: The functional approach. In R. E. Morris (Ed.), Encyclopedia of Social Work (16th ed.; pp. 1195-1206). New York: National Association of Social Workers.

Staudt, M., Howard, M. O., \& Drake, B. (2001). The operationalization, implementation, and effectiveness of the strengths perspective: A review of empirical studies. Journal of Social Service Research, 27(3), 1-21.

Sullivan, W. P., \& Rapp, C. (2002). Environmental context, opportunity, and the process of recovery: The role of strengths-based practice and policy. In D. Saleebey (Ed.), The strengths perspective in social work practice (3rd ed.; pp. 247-263). New York: Longman.
Towle, C. (1965). Common human needs. New York: National Association of Social Workers.

Ward, D., \& Mullender, A. (1991). Empowerment and oppression: An indissoluble pairing for contemporary social work. Critical Social Policy, 11(32), 21-30.

Waller, M., \& Yellow Bird, M. (2002). Strengths of First Nations peoples. In D. Saleebey (Ed.), The strengths perspective in social work practice (3rd ed.; pp. 48-62). New York: Longman.

Weick, A. (2000). Hidden voices. Social Work, 45, 395-402.

Weick, A., Rapp, C., Sullivan, W. P., \& Kisthardt, W. (1989). A strengths perspective for social work practice. Social Work, 34(6), 350-354.

White, M., \& Epston, D. (1990). Narrative means to therapeutic ends. New York: W.W. Norton.

Witkin, S. L. (2002). Introduction. In D. Saleebey (Ed.), The strengths perspective in social work practice (3rd ed.). New York: Longman.

Mel Gray, PhD, professor of social work and research professor, University of Newcastle. Correspondence: Mel.Gray@newcastle.edu.au; Research Institute for Social Inclusion and Wellbeing, University of Newcastle, University Drive, Callaghan, NSW 2308, Australia.

Manuscript received: July 9, 2009

Revised: October 14, 2009

Accepted: October 20, 2009
Get connected and stay ahead of the curve. Sign up for Families in Society E-Alerts.

E-Alerts highlight newly-published articles and preview upcoming items of interest to social and human service professionals and educators. Links for abstracts, tables of content, editorials, and other content are also provided atno cost. Register for free on FamiliesInSociety.org.

\section{FAMILIES IN SQIETY}

The Art, Science, and Practice of Social Work
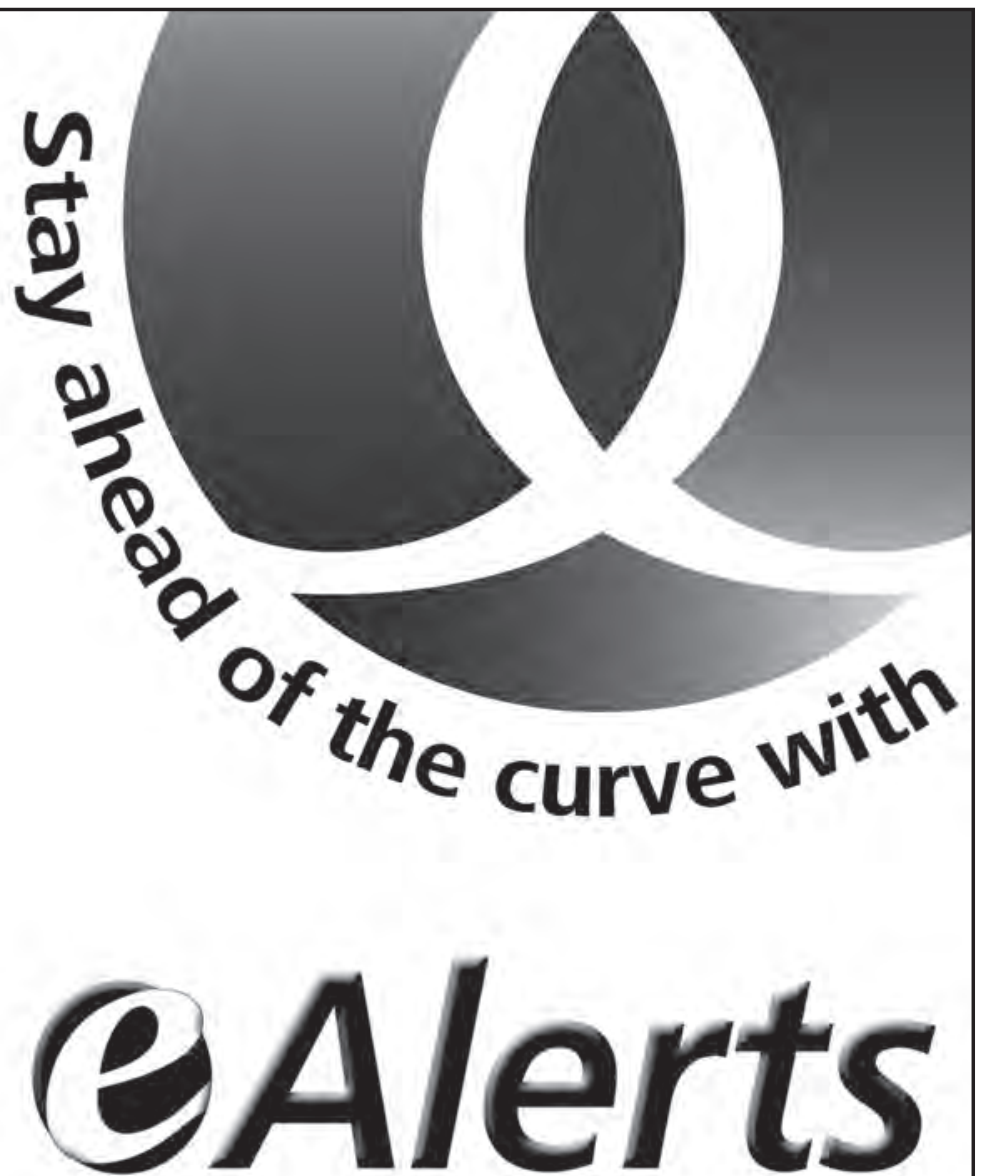